RESEARCH ARTICLE

\title{
PROBLEMATIKA OPERASIONALISASI DELIK PASAL 27 AYAT (3) UU ITE DAN FORMULASI HUKUM PERLINDUNGAN FREEDOM OF SPEECH DALAM HAM
}

\author{
Dhea Hafifa Nanda, Faishal Amirudin Hariyanta ${ }^{\bowtie}$ \\ Universitas Sebelas Maret \\ $\triangle$ dheahafifa@gmail.com; faishalamirudinfhuns68@gmail.com
}

\begin{abstract}
Freedom of Speech is a right that is protected by the State, but with the "existence of rubber" article 27 paragraph (3) of Law Number 11 of 2008 concerning Information and Electronic Transactions, it limits this freedom, besides that this article often creates a lot of social legal entanglement in the operation of the offense, especially used as a fortress by the ruler. The research method used by the author in this article uses normative legal research methods through literature study and uses a statutory approach with the aim of knowing the operational problems of defamation and insulting offenses in Article 27 Paragraph (3) of the ITE Law and Legal Formulation Article 27 Paragraph (3) as the protection of the right to freedom of expression in the concept of Human Rights
\end{abstract}

Keywords: Defamation, Freedom of Speech, Multi-interpretation Article, law enforcement, legal Protection.

Kebebasan Berpendapat atau freedom of speech merupakan hak yang dilindungi oleh Negara, namun dengan keberadaan pasal karet 27 ayat (3) Undang-Undang Nomor 11 Tahun 2008 mengenai Informasi dan Transaksi Elektronik membatasi kebebasan tersebut, selain itu pasal ini sering menimbulkan banyak jeratan hukum kemasyarakatan dalam operasionalisasi deliknya terlebih bila dipakai sebagai benteng oleh penguasa. Metode penelitian yang digunakan penulis dalam artikel ini menggunakan metode penelitian hukum normatif melalui studi kepustakaan dan menggunakan pendekatan perundang-undangan dengan tujuan untuk mengetahui mengetahui Problematika Operasionalisasi Delik Pencemaran Nama Baik dan Penghinaan dalam Pasal 27 Ayat (3) Dalam Undang-Undang ITE dan Formulasi Hukum Pasal 27 Ayat (3) sebagai perlindungan hak kebebasan berekspresi dalam konsep Hak Asasi Manusia

Kata Kunci: Pencemaran Nama Baik, Kebebasan berpendapat, Pasal MultiTafsir, Penegakan Hukum, Perlindungan Hukum 


\section{INTRODUCTION}

Teknologi informasi diyakini membawa keuntungan yang besar bagi setiap negara di dunia. ${ }^{1}$ Kemajuan teknologi juga telah menyederhanakan serta mempercepat komunikasi antar wilayah dan bahkan antar negara. Ketersediaan informasi guna mempelajari berbagai peristiwa di penjuru dunia melalui internet dengan begitu mudahnya, serta kemajuan dibidang financial technology. Artinya kemajuan teknologi telah merubah dunia menjadi tanpa batas dan telah menyebabkan perubahan sosial yang cepat. ${ }^{2}$

Perubahan sosial yang ditimbulkan juga dapat melahirkan bentuk-bentuk kejahatan baru. Penyalahgunaan kemajuan teknologi yang terjadi dalam cyber space atau dunia internet inilah yang selanjutnya dikenal dengan cybercrime. ${ }^{3}$ Banyak pihak yang menilai keberadaan hukum pidana dalam hal ini Kitab Undang-Undang Hukum Pidana tidak bisa menyentuh kejahatan baru tersebut, sehingga pemerintah menggagas lahirnya regulasi yang memberantas cybercrime yakni Undang-Undang Nomor 19 Tahun 2016 tentang Perubahan Atas Undang-Undang Nomor 11 Tahun 2008 tentang Informasi dan Transaksi Elektronik.

Namun dalam tataran praktek, penegakan hukum pidana dengan Undang-Undang Nomor 19 Tahun 2016 tentang Perubahan Atas Undang-Undang Nomor 11 Tahun 2008 tentang Informasi dan Transaksi Elektronik ini ternyata menimbulkan berbagai masalah hukum bagi orang-orang yang menggunakan sarana teknologi informasi untuk menyampaikan pendapat atau bahkan kritik di dalam media elektronik. Hal tersebut terjadi karena Undang-Undang Nomor 19 Tahun 2016 tentang Perubahan Atas Undang-Undang Nomor 11 Tahun 2008 tentang Informasi dan Transaksi Elektronik tidak saja mengatur masalah cybercrime sebagaimana yang diatur dalam convention on cybercrime. Tetapi juga mengatur perbuatan pidana tradisional berupa penghinaan yang menggunakan media teknologi informasi.

Tindak pidana penghinaan atau pencemaran nama baik beragam wujudnya antara lain menistakan, memfitnah, melapor secara memfitnah, dan menuduh secara memfitnah. ${ }^{4}$ Dalam Kitab Undang-Undang Hukum Pidana pencemaran nama baik diatur melalui Pasal 310-320 Buku Kedua (Kejahatan) Bab XVI Tentang Penghinaan. Undang-Undang Informasi dan Transaksi Elektronik mengatur tindak pidana pencemaran nama baik melalui media teknologi informasi komunikasi yang terdapat dalam Pasal 27 ayat 3 Undang-Undang Nomor 19 Tahun 2016 tentang Perubahan Atas Undang-Undang Nomor 11 Tahun 2008 tentang Informasi dan Transaksi Elektronik yang berbunyi: "Setiap orang dengan sengaja dan tanpa bak mendistribusikan dan/ atau mentransmisikan dan/ atau membuat dapat di aksesnya Informasi Elektronik dan/atau Dokumen Elektronik yang memiliki muatan penghinaan dan/atau pencemaran nama baik". Dengan ancaman pidana yang diatur dalam Pasal 45 ayat 3 UU ITE

\footnotetext{
${ }^{1}$ Budi Suhariyanto, Tindak Pidana Teknologi Informasi (Cybercrime) Urgensi Pengaturan dan Celah Hukumnya (Depok: PT. Rajagrafindo Persada, 2013), hal. 1.

2 Abdulla Wahid, Kejabatan Mayantara (Cyber Crime) (Bandung: Refika Aditama, 2005), hal. 9.

3 Devi Angeliawati, "Pertanggungjawaban Pidana Terhadap Pelaku Tindak Pidana Pencemaran Nama Baik (Studi Putusan Nomor: 6/Pid.Sus/2017/Pn Slr)," Celebes Cyber Crime Journal, 1.1 (2019), hal. 14.

4 Anton Hendrik Samudra, "Pencemaran Nama Baik Dan Penghinaan Melalui Media Teknologi Informasi Komunikasi Di Indonesia Pasca Amandemen UU ITE," Jurnal Hukum \& Pembangunan, 50.1 (2020), hal. 96.

5 Pasal 27 ayat (3) Undang-Undang Nomor 19 Tabun 2016 tentang Perubahan Atas Undang-Undang Nomor 11 Tabun 2008 tentang Informasi dan Transaksi Elektronik.
} 
ISSN (Print) 2338-1051, ISSN (Online) 2777-0818

dengan pidana penjara paling lama enam tahun dan/atau denda paling banyak Rp. 1.000.000.000,00 (satu miliar rupiah).

Namun keberadaan Pasal 27 ayat (3) tersebut menjadikan kebebasan warga negara untuk menyampaikan pendapat melalui media elektronik (dunia maya) menjadi terbatas. Seyogyanya kebebasan berpendapat bagi warga negara menjadi keharusan bagi pemerintah untuk melindungi, namun malah menjadi hal yang krusial. Selain itu dalam Pasal 28E ayat 3 Undang-Undang Dasar Tahun 1945 juga dijelaskan bahwa terdapat kebebasan berpendapat selama tidak melanggar ketentuan peraturan. Kebebasan mengeluarkan pendapat atau Freedom of Speech merupakan hak setiap warga negara dalam hal mengeluarkan pikiran atau gagasan baik secara lisan maupun tulisan secara bebas dan bertanggungjawab tanpa adanya tekanan serta sesuai dengan peraturan yang berlaku. Kebebasan tersebut ditujukan untuk mewujudkan perlindungan yang konsisten.

Keberadaan Pasal 27 ayat 3 seringkali dimanfaatkan oleh pemerintah atau penguasa sebagai "benteng" untuk menahan kritik dan protes dari warga negara atau pekerja. Selain itu, mengkriminalisasi penghinaan/ pencemaran nama baik juga dapat digunakan sebagai senjata mematikan untuk menekan opini tajam yang mengkritik pihak berwenang. ${ }^{6}$ Selain itu keberadaan pasal ini juga menimbulkan banyaknya multi tafsir sehingga disebut dengan "pasal karet", Pasal karet merupakan pasal yang tidak jelas tolak ukurnya dalam undangundang, pasal karet dahulunya digunakan sebagai alat politik warisan kolonial, yang muatannya multi tafsir dan sengaja dibuat untuk menjerat aktivis kemerdekaan Indonesia. Beberapa kasus seperti Prita Mulyasari, Fadli Rahim, Muhammad Arsyad yang terjerat pasal karet ini serta data Direktorat Tindak Pidana Siber Bareskrim Polri yang menyebutkan pidana terhadap pencemaran nama baik dan penghinaan paling banyak ditangani dan mendominasi dibandingkan cybercrime lainnya, Dari Januari sampai dengan November 2020 dengan total 1.743 kasus dibandingkan dengan penipuan sebanyak 1.295 kasus, dan kasus lain seperti pornografi, akses ilegal, ujaran kebencian, hoaks, manipulasi data, dan pengancaman. ${ }^{7}$ Banyaknya pandangan mulai dari revisi, dan penghapusan pasal-pasal karet UU ITE termasuk pasal 27 ayat 3 ini namun pembahasannya belum masuk dalam daftar Program Legislasi Nasional (Proglegnas) prioritas 2021.

Metode penelitian yang digunakan penulis dalam artikel ini menggunakan metode penelitian hukum normatif melalui studi kepustakaan dan menggunakan pendekatan perundang-undangan dengan tujuan untuk mengetahui Problematika Operasionalisasi Delik Pencemaran Nama Baik dan Penghinaan dalam Pasal 27 Ayat (3) Dalam UndangUndang ITE dan Formulasi Hukum Pasal 27 Ayat (3) sebagai perlindungan hak kebebasan berekspresi dalam konsep Hak Asasi Manusia

\footnotetext{
${ }^{6}$ Supriyadi Widodo Eddyono, Problem Pasal Penghinaan dan Pencemaran Nama Baik di Ranah Maya (Jakarta Selatan: Lembaga Studi dan Advokasi Masyarakat, 2014), hal. 3.

7 CNN Indonesia, "Polri Tangani 4.656 Kasus Siber, Pencemaran Nama Baik Dominan," CNN Indonesia, 2020.
} 


\section{RESULTS \& DISCUSSION}

\section{A. Problematika Operasionalisasi Delik Pencemaran Nama Baik dan Penghinaan dalam Pasal 27 Ayat (3) Dalam Undang-Undang ITE}

Perwujudan tujuan hukum harus menciptakan keadilan, diperlukan reformasi penegakan hukum dalam di Indonesia sesuai cita-cita yang didambakan yaitu keadilan yang memberikan kesejahteraan sosial bagi seluruh rakyat. ${ }^{8}$ Reformasi penegakan hukum yang baik ialah melalui pendekatan sistem hukum, Lawrence M. Friedman mengemukakan teori bahwa dalam sistem hukum terbagi menjadi 3 bagian, yakni substansi hukum, struktur hukum, dan budaya hukum. ${ }^{9}$ Substansi hukum merupakan norma-norma hukum, aturanaturan, asas-asas hukum yang baik dalam bentuk lisan ataupun tertulis, termasuk juga didalamnya putusan pengadilan. Sedangkan Struktur hukum merupakan badan-badan, institusi-institusi, aparat penegak hukum, yang meliputi kepolisian, kejaksaan, hakim, dan lain sebagainya. Bagian terakhir ialah budaya hukum (Kultur hukum) yang merupakan kepercayaan, keyakinan, kebiasaan, opini-opini, cara bertindak dan berfikir dari keseluruhan masyarakat mengenai hukum dan fenomena yang terjadi di dalam masyarakat yang berkaitan dengan hukum. ${ }^{10}$

Terdapat sebuah problematika dalam penegakan hukum mengenai tindak pidana pencemaran nama baik dan penghinaan yang diatur dalam Pasal 27 ayat (3) Undang-Undang Nomor 19 Tahun 2016 tentang perubahan atas Undang-Undang Nomor 11 Tahun 2008 tentang Informasi dan Transaksi Elektronik. Pasal tersebut dan sejumlah pasal lain dalam Undang-Undang Nomor 19 Tahun 2016 tentang perubahan atas Undang-Undang Nomor 11 Tahun 2008 tentang Informasi dan Transaksi Elektronik dikatakan sebagai "pasal karet". ${ }^{11}$

Beberapa kasus yang membuktikan bahwa perlu dilakukan reformasi dalam substansi pasal 27 ayat 3, yakni:12 kasus Prita Mulyasari sebagai orang pertama yang terjerat Pasal pencemaran nama baik ini setelah mengirimkan email mengenai keluhannya atas pelayanan Rumah Sakit Omni Internasional, yang tanpa sengaja menyebar luar di dunia maya; kemudian kasus Fadli Rahim yang dilaporkan karena menghina dan mencemarkan nama baik Ichsan Yasin Limpo yang menjabat sebagai Bupati Gowa Sulawesi Selatan karena kritikannya dalam aplikasi chat "Line" bahwa bupati tersebut otoriter; selain itu ada Herryberus Johan yang terkena pasal ini dari konten facebook, ada juga muhammad Arsyad, Fajriska Mirza, Deddy Endarto, dan banyak lagi. ${ }^{13}$

Berbagai kasus tersebut berujung pada pelaporan ke polisi, tindakan penahanan dan pemenjaraan. Salah satu kasus yang menimpa seorang ibu rumah tangga di Makassar 27

8 Ibid.

9 Ibid.

10 Oksep Adhayanto, Pery Rehendra Sucipto, dan Irman, "Membangun Sistem Politik yang Tidak Rentan Korupsi (Perspektif Perubahan Budaya Versus Perubahan Sistem)," Jurnal Selat, 5.1 (2017), hal. 56.

${ }_{11}$ Mara Ongku, "Ham dan kebebasan berpendapat dalam UUD 1945," Al WASATH Jurnal Ilmu Hukum, 2.1 (2021), hal. 32.

12 Conney Stephanie, “6 'Korban' yang Dijerat Pasal Karet UU ITE,” 16 Februari 2021 $<$ https://tekno.kompas.com/read/2021/02/16/15030007/6-korban-yang-dijerat-pasal-karet-uuite?page $=$ all $>$. Di akses Pada 01 Mei 2021 Pukul 17.50 WIB

13 Safenet, "Daftar Kasus Netizen yang Terjerat UU ITE," 2020 <https://id.safenet.or.id/daftarkasus/>. Di akses Pada 01 Mei 2021 Pukul 17.50 WIB 
ISSN (Print) 2338-1051, ISSN (Online) 2777-0818

Ayat 3 UU No 11 Tahun 2008 kembali menjerat korban. Seorang ibu bernama Yusniar di Makassar ditahan karena dianggap telah melakukan pencemaran nama baik di internet. Berawal dari kisruh rebutan warisan yang telah berlangsung lama dan mulai memanas tahun ini, lalu ada aksi perusakan yang kemudian membuat Yusniar menuliskan tanggapannya di Facebook. Namun siapa sangka ucapan yang tak merujuk pada seseorang itu membuatnya dikenai tuduhan pencemaran nama baik oleh anggota DPRD Kabupaten Jeneponto bernama Sudirman Sijaya. ${ }^{14}$

Ustadz Adam Amrullah yang merupakan Trainer Ruqyah Syar'iyyah di Trans7, Adam Amrullah berhasil ditahan di Polsek Bekasi Selatan. Hal itu, kabarnya terkait dengan pencemaran nama baik Senkom yang disebut Adam sebagai underbow LDII. Senkom melaporkan Adam terkait video yang diunggah Adam di Youtube. ${ }^{15}$

Prita Mulyasari dalam proses peradilan didakwa oleh Jaksa/Penuntut Umum Kejaksaan Negeri Tangerang dengan Pasal 310-311 KUHP Jo Pasal 27 ayat (3) Jo Pasal 45 ayat (1) UU No 11 Tahun 2008 namun hakim Pengadilan Negeri Tangerang pada 29 Desember 2009 memutuskan Prita Mulyasari Bebas dengan Putusan Pengadilan Negeri Tangerang Nomor 1269/PID.B/2009/PN.TNG Tentang Putusan Pengadilan Tingkat Pertama Atas Perkara Terdakwa Prita Mulyasari. ${ }^{16}$ Namun pada upaya hukum Kasasi yang diajukan oleh Pemohon Jaksa/Penuntut Umum Kejaksaan Negeri Tangerang yang diputus hakim pada 30 Juni 2011, menyatakan bahwa Prita Mulyasari besalah melakukan tindak pidana penghinaan/pencemaran nama baik sebagaimana yang termaktub pada Pasal 27 ayat (3) UU No 11 Tahun 2008 dengan Putusan Mahkamah Agung Kasasi Nomor 822 K/PID.SUS/2010 Tentang Putusan Mahkamah Agung Kasasi Atas Perkara Terdakwa Prita Mulyasari. ${ }^{17}$ Lantas Prita Mulyasari mengajukan upaya hukum Peninjauan Kembali dan telah diputus hakim dengan Putusan Mahkamah Agung Peninjauan Kembali Nomor 225 PK/PID.SUS/2011 Tentang Putusan Mahkamah Agung Peninjauan Kembali Atas Perkara Terdakwa Prita Mulyasari pada 12 September 2012 yang menyatakan bahwa ia bebas dari dakwaan. ${ }^{18}$ Pendapat yang berbeda diantara lembaga pengadilan (Pengadilan Negeri, Mahkamah Agung Kasasi dan Peninjauan Kembali) terkait objek tindak pidana penghinaan / pencemaran nama baik dalam Pasal 27 ayat (3) UU No 11 Tahun 2008 ini mengenai kasus Prita Mulyasari tersebut belum memberikan pemenuhan terhadap asas kepastian hukum, sehingga berpeluang untuk disalahtafsirkan atau multitafsir. Sebab hal ini menjadi ironi tatkala sebuah kritik maupun keluhan yang sangat berbeda sekli esensi nya dengan menyerang kehormatan seseorang dapat diancam pidana. Walaupun putusan akhir Peninjauan Kembali Prita Mulyasari inyatakan bebas, akan tetapi bisa dibayangkan hak-hak

${ }^{14}$ Koalis Peduli Demokrasi (Kopidemo) Makassar LBH Makassar, LBH Apik Makassar, YLBHM, "Yusniar Bebas dari Jerat Kriminalisasi, Bukti UU ITE Bermasalah," Lbhmakassar.org, 2017 <https://lbhmakassar.org/press-release/yusniar-bebas-dari-jerat-kriminalisasi-bukti-uu-ite-bermasalah/> Diakses Pada 28 Juni 2021 Pukul 13.00 WIB.

15 Supiyati, "Penerapan Pasal 27 Ayat 3 Undang-Undang No 19 Tahun 2016 Tentang Informasi Dan Transaksi Elektronik Terhadap Tindak Pidana Pencemaran Nama Baik Melalui Internet Sebagai Cybercrime Di Hubungkan Dengan Kebebasan Berekspresi," Pamulang Law Review, 2.1 (2020), hal. 31.

16 Direktori Putusan Mahkamah Agung, Putusan Pengadilan Negeri Tangerang Nomor 1269/PID.B/2009/PN.TNG, 2009.

17 Direktori Putusan Mahkamah Agung, Putusan Mabkamah Agung Kasasi Nomor 822 K/PID.SUS/2010, 2011.

18 Direktori Putusan Mahkamah Agung, Putusan Mabkamah Agung Peninjanan Kembali Nomor 225 PK/PID.SUS/2011, 2012. 
Prita Mulyasari yang terenggut karena putusan Kasasi yang menyatakan Prita Mulyasari bersalah dalam putusannya, sesungguhnya putusan tersebut telah merugikan Prita Mulyasari baik secara materil maupun secara immateril.

Pada perkara penghinaan dan/atau pencemaran nama baik dalam Putusan Mahkamag Agung No 2172 K/Pid.Sus/2015, Majelis hakim Kasasi menyatakan bahwa perbuatan terdakwa Yenike Venta Resti secara sah dan menyakinkan terbukti memenuhi unsur-unsur Pasal 27 ayat (3) jo. Pasal 45 ayat (3) UU ITE, yang pada faktanya kata-kata pada update status facebook terdakwa tidak jelas ditujukan kepada siapa karena tidak menyebut seseorang apalagi dengan nama Siti Anggraeni Hapsari, dan apabila dihubungkan dengan status perkawinan Siti Anggraeni Hapsari yang bersatus isteri sah dari Ir. Siswandi. Timbul permasalahan pertama, apakah Pertimbangan Hakim Dalam Putusan MA No 2172 K/Pid.Sus/2015, Yang Meyatakan Terdakwa Terbukti Memenuhi Unsur-unsur delik dalam Pasal 27 ayat (3) UU ITE, telah tepat. ${ }^{19}$ Kedua apakah vonis pidana penjara selama 3 bulan terhadap terdakwa telah tepat dihubungkan dengan tujuan pemidanaan. Berdasarkan tindak pidana pencemaran nama baik atau penghinaan baik dalam Pasal 27 ayat (3) UU ITE maupun pasal 310 KUHP dapat disimpulkan bahwa perbuatan yang dilakukan oleh Yenike Venta Resti bukan merupakan suatu perbuatan yang memenuhi unsur delik pencemaran nama baik. Akan tetapi pada unsur "memiliki muatan penghinaan dan/atau pencemaran nama baik" tidak kata-kata dalam facebook Yenike Venta Resti tidak jelas ditujukan kepada siapa karena tidak menyebut seseorang apalagi dengan nama Siti Anggraeni Hapsari sehingga tidak dapat dikatakan perbuatan tersebut melanggar kehormatan diri Siti Anggraeni Hapsari.

Jika ditelaah dalam Pasal 27 ayat (3) terdapat frasa "memiliki muatan" yang artinya tidak perlu dibuktikan adanya niat untuk menghina, dan penegak hukum hanya perlu membuktikan pelaku melakukan perbuatan sesuai unsur pasal tersebut (delik formil) berbeda dengan pengaturan dalam KUHP yang harus adanya niat. ${ }^{20}$ Pasal tersebut dan amandemen-nya tidak jelas menyebutkan subjek hukum yang di hina, dalam hal ini apakah hanya orang dan badan hukum, apakah termasuk juga jabatan seseorang, pasal ini hanya melarang perbuatan distribusi dan/atau transmisi dan/atau membuat dapat diaksesnya Informasi Elektronik dan/atau Dokumen Elektronik yang memiliki muatan penghinaan dan/atau pencemaran nama baik Berbeda halnya dengan pengaturan dalam KUHP yang pada hakikatnya harus ada kesengajaan untuk menyerang kehormatan seseorang. ${ }^{21}$ Permasalahan lain ialah amandemen UU ITE tidak mencantumkan pasal 310 dan pasal 311 KUHP secara rinci, melalui utusan Mahkamah Konstitusi Nomor 50//PUU-VI/2008 yang menyebutkan bahwa pasal kedua pasal KUHP tersebut sebagai acuan (delict genus) pasal 27 ayat 3 UU ITE tersebut.

Selain itu permasalahan penentuan sanksi pidana, secara sejarah dan perkembangan masyarakat mempengaruhi tujuan pemidanaan Tujuan pemidanaan dapat berorientasi pada pembalasan, utilitarian, reformasi, rehabilitas, gabungan, perlindungan hukum, pembebasan, dan lain sebagainya.22Pidana banyak digunakan sebagai Ultimum Remedium atau obat terakhir dalam hukum pidana, apabila fungsi hukum lain tidak dapat menyelesaikan

\footnotetext{
19 Direktori Putusan Mahkamah Agung, Putusan Mabkamah Agung No 2172 K/Pid.Sus/2015, 2016.

${ }^{20}$ Ibid.

${ }^{21}$ Ibid.

22 Ibid, hal. 1328.
} 
ISSN (Print) 2338-1051, ISSN (Online) 2777-0818

masalah. Ditinjau dari sanksi pidana pencemaran nama baik dan penghinaan dalam Pasal 45 UU ITE, dikatakan sebelum revisi, ancaman pidananya paling lama 6 tahun dan denda sebesar 1 milyar rupiah, tidak dijelaskan alasan penetapan sanksi yang tinggi tersebut dalam pembuatannya. ${ }^{23}$ Namun dijelaskan oleh Mahkamah Konstitusi mengeluarkan putusannya nomor 2/PUU-VII/2009 dikarenakan distribusi dan penyebaran informasi media elektronik relatif cepat dan luas, dan dapat menyebabkan dampak besar. Bahkan dengan sanksi yang tinggi tersebut, memudahkan penyidik untuk melakukan penahanan karena penahanan dapat terjadi dengan pengaturan pidana penjara 5 tahun atau lebih sesuai ketentuan KUHAP. ${ }^{24}$ Munculnya keberatan dari masyarakat yang mengajukan uji materi pasal 27 ayat (3) ke Mahkamah Konstitusi adanya revisi menyebabkan penurunan ancaman pidana menjadi 4 tahun. Menurut penulis ini sanksi 4 tahun penjara masih tergolong sanksi yang tinggi, penulis sedikit membandingkan pengaturan di dua negara, yang pertama di India, india mengatur pencemaran nama baik dalam hukum perdata dan pidananya, pidana pencemaran nama baik atau defamation diatur dalam Section 499 dan sanksinya pada Section 500 India Penal Code (IPC). Section 500 IPC merumuskan sanksi "Whoever defames another shall be punished with simple imprisonment for a term which may extend to two years, or with fine, or with both" India memberlakukan pidana kepada orang yang mencemarkan nama baik orang lain dengan pidana penjara sederhana yang dalam jangka waktu hingga 2 tahun, dan atau denda, dan atau keduanya. ${ }^{25}$ Selain itu singapura dalam Section 499 Singapore Penal Code sanksi pidana untuk pencemaran nama baik dapat dihukum dengan denda ditambah penjara hingga dua tahun. ${ }^{26}$ Dalam Portuguese Criminal Code diatur juga pencemaran nama baik mengenai pihak ketiga yang diancam penjara 6 bulan atau denda 240 hari, ataupun secara langsung terhadap orang tersebut dengan ancaman penjara 3 bulan atau denda sampai dengan 120 hari, jika pencemaran nama baik itu dilakukan publisitas dan merupakan fitnah, sanksi dinaikkan 1/3, apabila melalui media sanksi penjara dapat meningkat hingga 2 tahun atau denda minimal dari 120 hari, melalui perbandingan dari beberapa negara tersebut Indonesia masih mengedepankan pidana penjara dengan ancaman pidana penjara yang tinggi. ${ }^{27}$

Dilihat dari tujuan pemidanaan jelas pidana tersebut hanya bertujuan untuk melakukan pembalasan. Seperti yang telah disebutkan bahwa pidana digunakan sebagai ultimum remedium, seharusnya ada upaya hukum lain yang harus dilakukan seperti sarana administratif dan perdata.

Jika dirincikan permasalahan dalam Pasal 27 ayat (3) secara keseluruhan, yaitu: ${ }^{28}$ tidak adanya kejelasan unsur pencemaran dan baik dan penghinaan (subjek); tidak jelasnya objek pasal tersebut yang hanya individu, badan hukum, atau termasuk juga jabatan; ketidakjelasan dalam pertanggung jawaban, siapa yang bertanggung jawab, yang membuat, yang menyebarkan pencemaran nama baik tersebut; masih banyak yang bukan korban langsung

23 Ibid, hal. 1329.

24 Ibid, hal. 175

${ }^{25}$ Shivi, "Defamation Laws and Judicial Intervention: a Critical Study," ILI Law Review, 19 (2016),

26 Startup Decisions, "Singapore's Defamation Law," startupdecisions.com.sg <https://www.startupdecisions.com.sg/singapore/business-laws/defamation-law/>. Diakses Pada 01 Mei 2021 Pukul 18.33 WIB

27 Scott Griffen, BRIEFING: CRIMINAL DEFAMATION (The International Press Institute: Vienna / Austria, 2015), hal. 8.

28 Andi Haerul Karim, Nawi, dan Baharuddin, Op.Cit., hal. 1324. 
yang mengajukan aduan delik; tidak dimasukkannya doktrin pembelaan diri ataupun alasan pembenar untuk penghapusan pidana; tidak jelas ranahnya kedalam publik atau privat; ketidakjelasan sanksi pemidanaan; Ketidakjelasan perbedaan sesuatu yang bersifat kebebasan berpendapat, kritik, opini lain untuk informasi dan kepentingan publik padahal dalam Pasal 4 UU ITE dikatakan bahwa tujuan pembuatnnya ialah untuk mencerdaskan kehidupan bangsa sebagai bagian dari masyarakat informasi di cyberspace.

Dalam menilai efektivitas pasal haruslah melalui dua sisi, pengaturan dan penegakan atau penerapan (law enforcement). Dilihat dari pengaturan, pasal ini baik untuk melindungi orang dari cybercrime dan mempertahankan nama baik namun masih perlu adanya revisi dalam perumusan secara lex certa (terperinci, jelas dan cermat), lex stricta (secara tertulis), dan lex previa (tidak boleh berlaku surut), banyak hal dari substansinya, mulai dari pencantuman definisi, subjek, objek, unsur-unsur perbuatan, dan penegakan sanksi pidanannya. Sedangkan dilihat dari penegakannya harus dicermati case by case. ${ }^{29}$

Salah satu dampak buruk terjadinya multitafsir pasal ini ialah menurunnya demokrasi rakyat Indonesia, melalui kompas, lembaga Indikator Politik Indonesia telah melakukan survey kepada 1.200 responden secara acak pada tanggal 24-30 September 2020, dari pertanyaan "apakah warga makin takut berpendapat", membuahkan hasil sebanyak 21,9\% setuju, 47,7\% agak setuju. ${ }^{30}$ Walaupun pada awalnya pasal ini digunakan sebagai perlindungan dari hal yang menyebabkan kerugian seseorang, dan perlu dilakukan pembatasan, selaras dengan Teori John Stuart Mill mengenai Harm Principle bahwa kebebasan seseorang dibatasi oleh kebebasan orang lain serta teori Roscoe Pound, bahwa hukum digunakan sebagai alat rekayasa sosial untuk mengendalikan nilai-nilai sosial. Takutnya dapat menyebabkan akan timbulnya trauma sosial dalam masyarakat sehingga takut untuk berpendapat dalam dunia maya. Trauma sosial merupakan kondisi trauma secara sosiaL psikologis yang mengakibatkan penderitaan pada banyak orang yang mengalami satu peristiwa traumatik yang sama secara bersama. ${ }^{31}$

Undang-Undang Nomor 40 Tahun 1999 tentang pers sebenarnya telah mengatur penyampaian dan penyajian suatu pendapat akan dilakukan publikasi, seperti wajib menjaga etika dan estetika berbicara maupun menyampaikan pendapat, tidak diperbolehkan merusak harga diri orang lain dan tidak boleh menyebabkan keresahan dalam masyarakat. ${ }^{32}$ Dalam melakukan kriminalisasi menurut Hoefnagel perlu menjaga ultimum remedium dan menjaga tidak terjadinya over criminalization, dengan mempertimbangkan, yaitu: ${ }^{33}$ tidak memakai hukum pidana secara emosional; tidak memakai hukum pidana untuk mempidana apabila tidak jelas subjek ataupun dampak kerugiannya; tidak memakai hukum pidana jika timbulnya dampak kerugian dari pemidanaan lebih besar dari pidana yang dirumuskan; tidak memakai hukum pidana yang ditentang oleh masyarakat secara luas; tidak memakai hukum pidana apabila pengaplikasian dinilai tidak efektif; harus menilai secara khusus skala prioritas

29 Ibid, hal. 1323.

30 Rezeky Setyawan Amir, Ahmad, dan Baharuddin, Op.CIt., hal. 1503.

31 Agung Yundi Bahuda Sistawan, "Kebebasan Berekspresi Menurut Pasal 27 Ayat (3) Undang Undang Informasi dan Transaksi Elektronik," JUSTITLA JURN AL HUKUM FAKULTAS, 3.1 (2019), hal. 6.

32 Mara Ongka, Op.Cit., hal. 37.

33 Hisbul Luthfi Ashsyarofi, "Penerapan Asas Ultimum Remedium Dalam Penegakan Hukum Tindak Pidana Undang-Undang Informasi Dan Transaksi Elektronik,” Yurispruden, 4.1 (2021), hal. 32. 
ISSN (Print) 2338-1051, ISSN (Online) 2777-0818

kepentingan pengaturan; menjadi upaya represif dan wajib didayagunakan secara serentak dengan saran pencegahan

Selain usulan mengenai revisi hingga penghapusan pasal 27 ayat 3 UU ITE yang dinilai multi tafsir. Pengacara Hotman Paris Hutapea menyampaikan usulan kepada Menteri Koordinator Bidang Politik, Hukum, dan Keamanan Mafmud Md, bahwa pencemaran nama baik itu sebaiknya dibawa ke ranah perdata bukuan pidana, Hotman Paris membandingkan dengan Inggris, di negara tersebut pencemaran nama baik masuk ke dalam ranah perdata dalam Defamation Act of 2013 United Kingdom. ${ }^{34}$ Penulis berpendapat sebaiknya tetap mengutamakan semua sistem hukum, baik perdata maupun pidana, dengan pidana sebagai ultimatum remedium. Namun dengan revisi terlebih dahulu pada pasal 27 yang sering menjadi alat kriminalisasi korban masyarakat biasa, aktivis, wartawan, ataupun lawan politik. Supaya Pasal ini tidak condong ke atas saja namun juga kebawah, dan bukan lagi instrumen pembalasan dendam aja. Penegakan dari segi struktur juga harus mengarah pada konsep restorative justice, dengan proses mediasi terlebih dahulu di tingkat kepolisian pada proses penyelidikan dan penyidikan untuk saling bertemu, mencari dan menghasilkan cara terbaik mengatasi dampak atau akibat kejahatan sesuai amanat Surat Edaran nomor 8/vii/2018 mengenai penerapan keadilan restorative justice dan Keputusan Direktur Jenderal Badan Peradilan Umum Mahkamah Agung RI Nomor 1691/DJU/SK/PS.00/12/2020 tentang Pemberlakuan Pedoman Penerapan Keadilan Restorative. ${ }^{35}$ Pendekatan Restorative ini ditegaskan Marman Effendi bahwa dalam menempatkan Restorative justice difokuskan keseimbangan kepentingan pelaku dan korban. Bagir Manan juga menyatakan Restorative justice membangun partisipasi bersama antara pelaku, korban, dan kelompok masyarakat menyelesaikan pertiwi tindak pidana. Kepolisian juga harus memilah terlebih dahulu kasus pencemaran nama baik mana yang dapat diproses, Kapolri Jenderal Listyo Sigit Prabowo melalui Surat Telegram Nomor ST/339/II/RES.1.1.1./2021 tertanggal 22 Februari 2019 memberikan pedoman penanganan hukum cybercrime kepada penyidik Polri yang salah satunya menyebutkan kasus pencemaran nama baik, fitnah, atau penghinaan diselesaikan dengan cara restorative justice atau mediasi antara korban dan tersangka. ${ }^{36}$ Selain itu untuk penegakan hukum dalam cyberspace terdapat Virtual Police, yang sebagai pengawasan, pemberi peringatan, memberi edukasi, dan pencegahan potensi gybercrime, pelaksanaan virtual police ini telah dituangkan dalam Surat Edaran (SE) Kapolri bernomor SE/2/11/2021 Tentang Kesadaran Budaya Beretika Untuk Mewujudkan Ruang Digital Indonesia yang Bersih, Sehat dan Produktif. ${ }^{37}$ Selain substansi hukum dan struktur hukum, budaya hukum juga hal yang harus diperhatikan. Diperlukan edukasi lebih terhadap masyarakat tentang pentingnya kebebasan berpendapat namun tetap memperhatikan substansi konten yang dibuat dengan memahami literasi digital atau medua sebagai wujudkan kepedulian masyarakat pada efek negatif media massa dengan kemampuan kognitif ataupun teknikal dalam menggunakan

34 Kadek Melda Luxiana, "Berkaca dari Inggris, Hotman Paris Usul ke Mahfud UU ITE Jadi Perdata," detik.com, $2021<$ https://news.detik.com/berita/d-5500922/berkaca-dari-inggris-hotman-paris-usul-kemahfud-uu-ite-jadi-perdata>. Diakses 01 Mei 2021 Pukul 19.00 WIB

35 Ashsyarofi, Op.Cit,.hal. 39.

36 Monika Suhayati, "Larangan Penghinaan dan/atau Pencemaran Nama Baik Dalam Pasal 27 Ayat (3) UU ITE," Info Singkat, 13.5 (2021), hal. 5.

37 Tsarina Erdianto, "Mengenal Virtual Police: Definisi, Dasar Hukum, hingga Polemiknya," Kompas.com, $2021<$ https://nasional.kompas.com/read/2021/03/17/14414171/mengenal-virtual-policedefinisi-dasar-hukum-hingga-polemiknya?page=all>. Diakses 01 Mei 2021 Pukul 19.00 WIB 
informasi, dan memilah informasi yang dianggap perlu atau tidak. ${ }^{38}$ Meningkatkan budaya "tidak membawa perasaan" atau sangat emosional ketika melihat kritikan, karena belum tentu hal tersebut menimbulkan kerugian pada dirinya, mengurai budaya "pembalasan dendam" yang membuat meningkatnya aduan pencemaran nama baik dan penghinaan.

\section{B. Formulasi Hukum Pasal 27 Ayat (3) sebagai perlindungan hak kebebasan berekspresi dalam konsep Hak Asasi Manusia}

Setiap warga negara Indonesia mempunyai hak untuk diakui, mendapat jaminan, perlindungan dan memperoleh kepaatian hukum secara adil dan hak untuk diperlakukan sama di hadapan hukum sesuai Pasal 28D UUD NRI 1945. Pasal tersebut merupakan bukti bahwa Indonesia menjunjung tinggi Hak Asasi Manusia dan atas hak tersebut masyarakat mendapat perlindungan hukum Indonesia sebagai negara menjunjung tinggi Hak Asasi Manusia. Ketentuan lain Undang-Undang Dasar Tahun 1945 telah menjadi basic law yang wajib dipatuhi oleh Negara ialah Pasal 28 E ayat (3) Undang Dasar Tahun 1945 dinyatakan bahwa setiap orang berhak atas kebebasan berserikat, berkumpul, dan mengeluarkan pendapat, negara menjamin hal tersebut seluas-luasnya mulai dari bentuk persuatif maupun massif seperti unjuk rasa atau demonstrasi ${ }^{39}$ Jaminan hak Kebebasan berpendapat juga telah diatur secara Internasional, yakni dalam Pasal 19 Universal Daclaration of human rights (UDHR) atau Deklarasi Universal Hak Asasi Manusia (DUHAM) Tahun 1948, Kebebasan berpendapat atau freedom of speech menurut dinilai penting melalui 4 komponen, yakni dikarenakan menjamin pemenuhan diri dan keberhasilan mengeluarkan Keseluruhan potensi individu; digunakan sebagai upaya mencari kebenaran substansial dan sebagai hasil perkembangan pengetahuan dengan cara mendengar seluruh sudut pertanyaan, mempertimbangkan semua kemungkinan, menilai suatu pernyataan dengan pernyataan lain yang kontras, dan memanfaatkan seluruh pemikiran berbeda dengan optimal; supaya individu dapat ikut berpartisipasi dalam suatu proses pengambilan keputusan terkhusus dalam politik; dapat menciptakan masyarakat dan negara untuk tercapainya stabilitas dan adaptasi. ${ }^{40}$

Dapat dipahami bahwa sudah tugas wajib Pemerintah untuk melindungi adanya kebebasan berpendapat namun disisi lain juga harus melindungi sesorangan yang merasa dirugikan dari kebebasan berpendapat itu. Setiap warga negara memang mempunyai hak asasi manusia yang telah dilindungi sebagai amanat dasar negara, namun diperlukan suatu pembatasan sebagai wujud keseimbangan dan alat penyelesaian permasalahan pemenuhan Hak serta wujud perlindungan kepada kedua pihak yang dikritik maupun yang mengutarakan pendapat. ${ }^{41}$

Untuk mewujdukan keseimbangan tersebut dibutuhkan pembatasan, hak asasi manusia dalam article 4 ICCPR dibagi menjadi dua bagian, yakni hak yang tidak dapat dibatasi atau dihilangkan disebut Non-derogable rights seperti hak hidup, terlepas dari

38 Hana Silvana dan Cecep, "Pendidikan Literasi Digital Di Kalangan Usia Muda Di Kota Bandung," Pedagogia: Jurnal Ilmu Pendidikan, 16.2 (2018), hal. 147.

39 Mara Ongku, Op.Cit, hal. 30.

40 Mara Ongku,Op.Cit., hal. 31.

41 Sean Clara Thamrun, "Delik Pencemaran Nama Baik Dalam Undang-Undang Informasi Dan Transaksi Elektronik Ditinjau Dari Prespektif HAM," Jurnal Education and development, 8.2 (2020), hal. 203. 
ISSN (Print) 2338-1051, ISSN (Online) 2777-0818

penyiksaan dan perlakukan buruk, hak diakui sebagai subjek hukum. ${ }^{42}$ Kemdian bagian selanjutnya ialah hak yang yang dapat dibatasi atau disebut derogable rights. Kebebasan berpendapat masuk dalam deeogable rights sesuai pasal 20 ICCPR yang menerangkan adanya pembatasan hak berpendapat dalam bentuk "audio tulisan atau gambar yang berisikan suatu propaganda untuk perang serta dalam hal hak berekspresi akan kebencian atas kebangsaan, ras, agama. ${ }^{43}$ Pasal 19 International Convenant on Civil Political Right (ICCPR) yang telah di ratifikasi dalam Undang-Undang Nomor 12 Tahun 2005 Konvenan Internasional Tentang Hak-Hak Sipil dan Politik (KIHSP), dalam pasal ini terdapat pembahasan pembatasan yang diperbolehkan disebut three part test, yakni hanya dapat dengan menggunakan undangundang, hanya dengan tujuan yang telah disebutkan dalam Pasal 19 ICCPR, dan pembatasan bertujuan untuk melindungi dan menjamin tujuan dari Pasal 19 ICCPR. ${ }^{44}$

Pasal 27 ayat 3 Undang-Undang Informasi dan Transaksi Elektronik mengatur tindak pidana pencemaran nama baik dan penghinaan melalui media teknologi informasi komunikasi yang berbunyi: 45

"Setiap orang dengan sengaja dan tanpa hak mendistribusikan dan/atau mentransmisikan dan/atau membuat dapat di aksesnya Informasi Elektronik dan/atau Dokumen Elektronik yang memiliki muatan penghinaan dan/atau pencemaran nama baik.".

Dalam pasal tersebut terdapat pembatasan "mendistribusikan", "mentransmisikan" "membuat dapat diaksesnya" objek pembatasannya "Dokumen Elektronik" bermuatan penghinaan atau pencemaran nama baik. Dengan ancaman pidana yang diatur dalam Pasal 45 ayat 3 UU ITE dengan pidana penjara paling lama enam tahun dan/atau denda paling banyak Rp. 1.000.000.000,00 (satu miliar rupiah). Dapat diuraikan unsur dari Pasal 27 ayat 3 yaitu dinyatakan bahwa orang yang dimaksudkan dalam pasal tersebut merupakan orang perseorangan maupun badan hukum. Jadi, orang perseorangan baik warga negara Indonesia maupun warga negara asing dan/atau badan hukum yang terbukti memenuhi unsur ketentuan pasal tersebut diancam dengan pidana. Dengan sengaja dalam pasal tersebut tidak dijelaskan pengertian dari kata "sengaja". Dalam KUHP dicantumkan: "Kesengajaan adalah kemauan untuk melakukan atau tidak melakukan perbuatan-perbuatan yang dilarang atau diperintahkan oleh undang-undang". Dapat disimpulkan bahwa kesengajaan sebagai perbuatan yang dikehendaki dan si pelaku menginsafi bahwa perbuatan itu dilarang dan diancam hukuman.

Kebebasan mengeluarkan pendapat merupakan hak setiap warga negara dalam hal mengeluarkan pikiran atau gagasan baik secara lisan maupun tulisan secara bebas dan bertanggungjawab tanpa adanya tekanan serta sesuai dengan peraturan yang berlaku. Kebebasan tersebut ditujukan untuk mewujudkan perlindungan yang konsisten. ${ }^{46}$

${ }^{42}$ Fadilah Raskasih, "Batasan Kebebasan Berpendapat Melalui Media Elektronik Dalam prespektif HAM Dikaitkan Dengan Tindak Pidana Menurut UU ITE," Jurnal Equitable Journal Law: Jurisprudence Approach, 5.2 (2020), hal. 8.

${ }^{43}$ Della Luysky Selian dan Cairin Melina, "Kebebasan Berekspresi Di Era Demokrasi: Catatan Penegakan Hak Asasi Manusia," Lex Scientia Law Review, 2.2 (2018), hal. 196.

${ }^{44}$ Rezeky Setyawan Amir, Ahmad, dan Baharuddin, hal. 1512.

45 Pasal 27 ayat 3 Undang-Undang Nomor 19 Tabun 2016 tentang Perubahan Atas Undang-Undang Nomor 11 Tahun 2008 tentang Informasi dan Transaksi Elektronik.

46 Ervilia Agustine Wiharsianti, "Hak Asasi Manusia: Kebebasan Berpendapat," Kompasiana, 2014 https://www.kompasiana.com/erviliaagustine/hak-asasimanusia-kebebasanberpendapat_54f98577a3331140548b4836, diakses Pada 01 Mei 2021 Pukul 20.00 WIB

(C) Author(s). This work is licensed under a Creative Commons Attribution 4.0 International License . Published by Postgraduate Program, Master of Laws, Faculty of Law, Universitas Sebelas Maret, Indonesia 
Melalui hal tersebut untuk mewujudkan formulasi yang ideal sebgai perlindungan hak kebebasan dibutuhkan kebijakan kriminal, dimana menjadi bagian penting dari perlindungan masyarakat dan pencapaian social welfare. Kebijakan kriminal dilakukan dengan fungsionalisasi hukum (penal) dan dungsionalisasi tanpa hukum pidana (non penal). ${ }^{47}$

Bila ditelaah dalam melalui undang-undang nomor 9 tahun 1998 , terdapat 5 asas yang dapat digunakan sebagai landasan kebebasan berpendapat namun juga bertangggung jawab, yakni asas keseimbangan antara hak dan kewajiban; Asas musyawarah dan mudakat; asas kepastian hukum dan keadilan; asas proposionalitas; kemudian asas mufakat. ${ }^{48}$ Indonesia memiliki pembatan yang lebih luas dibandingkan konvensi internasional, yang juga memasukan adanya hak moral. Hak moral ialah hak yang didapat berdasarkan norma dan nilai moral dna menjadi martabat luhur yang melekat pada manusia. ${ }^{49}$

Standar- standar nilai moral dalam mengutarakan kebebasan berpendapat harus disesuaikan dengan ideologi bangsa yakni pancasila. Pancasila merupakan bingkai identitas bangsa yang mengandung cita hukum dan moral seyogyanya diterapkan disetiap permasalahan di Indonesia. Istilah "bhineka tunggal ika" dalam pancasila layaknya diterapakn dalam demokrasi mengutarakan suara di Indonesia. Menurut pendapat thomas pureklolon dalam terwujudnya kebebasan bependapat selaras dengan mekanisme yang disumberkan dalam norma yang belaku di masyarakat, dalam hal ini pancasila, undangundang dasar, dan peraturan lainnya. ${ }^{50}$ Kebebasan berpendapat harus dibatasi oleh ketuhanan, menjunjung kemanusiaan, persatuan, kerakyaktan dan keadilan social. ${ }^{51}$ Berpendapat diihat dari sisi Ketuhanan haruslah dilihat supaya orang dalam berpendaat menghargai dan menghormati kepercayaan indovidu maupun kelompok; Dari sisi kemanusiaan yang adil dan beradab, berpendapat haruslah dalam batasan melihat hak kodrat manusia, tidaklah berpendapat yang mengacam hak hidup, dan hak dasar lain yang diakui oleh konstitusi; Sisi persatuan, berpendapat wajiblah terkandung rasa persatuan mengingat bahwa Indonesia memiliki banyak budaya, harusnya menghargai setiap budaya dan perbedaanya; Sisi kerakyatan, dalam berpendapat ialah ketika terdapat perbedaan harus diselesaikan secara musyawarah demi kepentingan umum; kemudian dari sisi keadiaj sosial, yakni berpendapat tidak merugikan atau menggangu hak mayoritas dan hak minoritas supaya tetap terlindungi. ${ }^{52}$

Diperlukan suatu penegasan yang rigid untuk membedakan kritik dan informasi tidak benar (hoax) yang tak berdasar. Terdapat beberapa kriteria yang dapat dijadikan acuan dalam menyampaikan pendapat, yaitu dapat di buktikan kebenaran informasi; didapat melalui pengalaman sendiri yang bisa dipertanggungjawabkan; didapat melalui pengalaman orang lain yang telah ditelaah dan dikaji; bertujuan untuk kepentingan orang banyak; tidak

47 Fadilah Raskasih, Op.Cit. hal. 10.

48 Christyana Olivia Dewi dan MH Dr. Johnny Lembong, SH., MH Dr. Jemmy Sondakh, SH., "Perspektif Penanganan Perkara Tindak Pidana Pencemaran Nama Baik Terkait Dengan Impelementasi Hak Kebebasan Berpendapat Ditinjau Dari Hukum Pidana Dan Hak Asasi Manusia," Lex Et Societatis, 6.4 (2018), hal. 70 .

49 Ibid.

50 Khotbatul Laila, "Hukum Progresif sebagai Solusi Kebebasan Berpendapat dengan Asas Demokrasi Pancasila," Jurnal Cakrawala Hukum, 10.2 (2019), hal. 182.

51 Ibid., hal. 183.

52 Ibid. 
ISSN (Print) 2338-1051, ISSN (Online) 2777-0818

termuat propaganda yang menimbulkan gangguan ketertiban umum dan keamanan negara. ${ }^{53}$

Dalam rancangan Undang-Undang tahun 2018 mengatur hukum pidana yang berdasarkan nilai pancasila, sehingga disusun harus memenuhi unsur kesimbwngan dan integratif. Namun tetap saja pengaturan pencemaran nama baik dan penghinaan dalam RUU Ini tidak seluas dalam UU ITE dalam unsur perbuatannya. ${ }^{54}$ Pada UU ITE yang tidak menjelaskan secara explisit mengenai pembatasan delik oencemaran nama baik sehingga masih menimbulan pemrasalahan kritik. Presiden Joko Widodo telah mendesak untuk dibuatnya pedoman intepretasi secara resmi mengenai pasal 27 ayat (3) tersebut kepada TNI-Polri dan menyuruh kepolisian untuk lebih cermat dan twliti dalam pengaduan pencemaean nama baik. Pedoman intepretasi ini bertujuan untuk menghilangkan multi tafsir UU ITE namun juga tidak memenuhi kepastian hukum, revisi undang-undang memiliki kesempatan yang besar. ${ }^{55}$ Maka perlu diperluka revisi undang-undang ini supaya lebih jelas dan tegas serta tidak menimbulkan multitafsir. Dikarenakan Indonesia merupakan negara hukum yang menganut asas legalitas serta adanya prinsip siracusa Principle yang telah disebutkan dalam the limitation and derogatuon provisions Dalam Internasional conenvant on civil and politicial rights bahwa batasan harus di muat secara jelas untuk kepentingan hak dilindungi dan dapat diakses oleh semua orang serta memiliki konsekuensi yuridis akan dampaknya. ${ }^{56}$

Dalam perumusan kebijakan tindak pidana dapat melihat dari pendekatan perbandingan di luar negara mengenai pencemaran nama baik dan penghinaan. Di negara Inggris Ratu Elizabeth II menjelaskan adanya refprmasi emcemaran nama baik yang termuat pada RUU Lord Lester dari Herne Hill. ${ }^{57}$ Reformasi tersebut meningkatkan hak kebebasan berpendapat namun juga membagasi standar yuridiksi. Terdapat konsep "Fair comment" yaitu suatu bentuk pembelaan bersama terhadap tindak pidana pencemaran nama baik dan fitnah sebagai jaminan kebebasan pers untuk mengungkapkan pernyataan yang berkepentingan umum.Fair comment ini dimaknai dengan tujuan komentar yang ridak terdapat niat jelek, dendam, atau menyakiti orang lain. ${ }^{58}$

\section{CONCLUSION}

Problematika Operasionalisasi Pasal 27 Ayat (3) UU ITE dapat dilihat dari subtansi pasal yang masih multi tafsir, struktur hukum dimana masih banyak kasus mengenai orang yang terjerat oleh pasal ini, sedangkan dari kultur hukum masih banyak masyarakat yang dengan asal dan tidak beretika dalam mengutarakan pendapat serta masyarakat yang tidak

53 Fadilah Raskasih, Op.Cit., hal. 17.

54 Fifink Praiseda Alviolita dan Barda Nawawi Arief, "Kebijakan Formulasi Tentang Perumusan Tindak Pidana Pencemaran Nama Baik Dalam Pembaharuan Hukum Pidana Di Indonesia," Law Reform, 15.1 (2019), hal. 138.

55 CNN Indonesia, "Pedoman Interpretasi UU ITE di Tengah Desakan Revisi Pasal," CNN Indonesia, 2021 <https://www.cnnindonesia.com/nasional/20210218120427-20-607829/pedoman-interpretasi-uuite-di-tengah-desakan-revisi-pasal> Diakses Pada 28 Juni 2021 Pukul 15.00 WIB.

56 Nanda Yoga Rohmana, "Prinsip-Prinsip Hukum Tentang Tindak Pidana Penghinaan Dan Pencemaran Nama Baik Dalam Perpspektif Perlindungan Hak Asasi Manusia," Yuridika, 32.1 (2017), hal. 117 <https://doi.org/10.20473/ydk.v32i1.4831>.

57 Alviolita dan Arief, hal. 139.

58 Alviolita dan Arief, hal. 139. 
bisa membedakan kritik dan hinaan / pencemaran nama baik sehingga langsung melakukan aduan. Melalui problematika ini dibutukan formulasi Hukum Pasal 27 Ayat (3) sebagai perlindungan hak kebebasan berekspresi dalam konsep Hak Asasi Manusia. Sesuai jaminan perlindungan dalam Internasional dan cita hukum Negara Indonesia harus melindungi baik hak berpendapat seseorang maupun hak sesorang akan ancaman yang merugikannya. Maka walaupun freedom of speech diakui sebagai HAM namun diperlukan pembatsanpembatasan agar tidak merugikan hak orang lain. Pembatasan tersebut haruslah mengedepankan nilai-nilai moral, nilai moral di Indonesia sendiri tercantum dalam Pancasila sehingga dalam mengutarakan pendapat terlebih melalui media elektronik orang tersebut juga harus memperhatikan nilai pancasila di dalamnya.

\section{REFERENCES}

\section{Buku}

Didik M. Arif, Mansur, dan Elisataris Ghultom, Cyber Law: Aspek Hukum Teknologi Informasi, Refika Aditama, Bandung, hlm. 9-10. (Bandung: Refika Aditama, 2005)

Eddyono, Supriyadi Widodo, Problem Pasal Penghinaan dan Pencemaran Nama Baik di Ranah Maya (Jakarta Selatan: Lembaga Studi dan Advokasi Masyarakat, 2014)

Griffen, Scott, BRIEFING : CRIMINAL DEFAMATION (Vienna / Austria, 2015)

Soesilo, R., Kitab Undang-Undang Hukum Pidana (Bogor: Politea, 1995)

Suhariyanto, Budi, Tindak Pidana Teknologi Informasi (Cybercrime) Urgensi Pengaturan dan Celah Hukumnya (Depok: PT. Rajagrafindo Persada, 2013)

Wahid, Abdulla, Kejahatan Mayantara (Cyber Crime) (Bandung: Refika Aditama, 2005)

Jurnal

Adhayanto, Oksep, Pery Rehendra Sucipto, dan Irman, "Membangun Sistem Politik yang Tidak Rentan Korupsi (Perspektif Perubahan Budaya Versus Perubahan Sistem)," Jurnal Selat, 5.1 (2017)

Agung Yundi Bahuda Sistawan, "Kebebasan Berekspresi Menurut Pasal 27 Ayat (3) Undang Undang Informasi dan Transaksi Elektronik," JUSTITLA JURNAL HUKUM FAKULTAS, $3.1(2019)$

Alviolita, Fifink Praiseda, dan Barda Nawawi Arief, "Kebijakan Formulasi Tentang Perumusan Tindak Pidana Pencemaran Nama Baik Dalam Pembaharuan Hukum Pidana Di Indonesia," Law Reform, 15.1 (2019)

Andi Haerul Karim, Syahruddin Nawi, dan Hamza Baharuddin, "Reformulasi Penerapan Tindak Pidana Pencemaran Nama Baik Melalui Media Elektronik Berdasarkan Undang-Undang Informasi \& Transaksi Elektronik," Journal of Lex Generalis (JLG), 2.3 (2021)

Angeliawati, Devi, "Pertanggungjawaban Pidana Terhadap Pelaku Tindak Pidana Pencemaran Nama Baik (Studi Putusan Nomor: 6/Pid.Sus/2017/Pn Slr)," Celebes Cyber Crime Journal, 1.1 (2019) 


\section{ISSN (Print) 2338-1051, ISSN (Online) 2777-0818}

Ashsyarofi, Hisbul Luthfi, "Penerapan Asas Ultimum Remedium Dalam Penegakan Hukum Tindak Pidana Undang-Undang Informasi Dan Transaksi Elektronik," Yurispruden, 4.1 (2021)

Dewi, Christyana Olivia, dan MH Dr. Johnny Lembong, SH., MH Dr. Jemmy Sondakh, SH., "Perspektif Penanganan Perkara Tindak Pidana Pencemaran Nama Baik Terkait Dengan Impelementasi Hak Kebebasan Berpendapat Ditinjau Dari Hukum Pidana Dan Hak Asasi Manusia," Lex Et Societatis, 6.4 (2018)

Fadilah Raskasih, "Batasan Kebebasan Berpendapat Melalui Media Elektronik Dalam prespektif HAM

Dikaitkan Dengan Tindak Pidana Menurut UU ITE," Jurnal Equitable Journal Law: Jurisprudence Approach, 5.2 (2020)

Hsb, Mara Ongku, "Ham dan kebebasan berpendapat dalam UUD 1945," Al WASATH Jurnal Ilmu Hukum, 2.1 (2021)

Laila, Khotbatul, "Hukum Progresif sebagai Solusi Kebebasan Berpendapat dengan Asas Demokrasi Pancasila," Jurnal Cakrawala Hukum, 10.2 (2019)

Rezeky Setyawan Amir, Kamri Ahmad, dan Hamza Baharuddin, "Penghapusan Pidana Demi Kepentingan Umum Dan Membela Diri Pada Kasus Penghinaan Di Media Sosial," Journal of Lex Generalis (JLG), 2.3 (2021)

Rohmana, Nanda Yoga, "Prinsip-Prinsip Hukum Tentang Tindak Pidana Penghinaan Dan Pencemaran Nama Baik Dalam Perpspektif Perlindungan Hak Asasi Manusia," Yuridika, 32.1 (2017)

Samudra, Anton Hendrik, "Pencemaran Nama Baik Dan Penghinaan Melalui Media Teknologi Informasi Komunikasi Di Indonesia Pasca Amandemen UU ITE," Jurnal Hukum \& Pembangunan, 50.1 (2020)

Selian, Della Luysky, dan Cairin Melina, "Kebebasan Berekspresi Di Era Demokrasi: Catatan Penegakan Hak Asasi Manusia," Lex Scientia Law Review, 2.2 (2018)

Shivi, "Defamation Laws and Judicial Intervention: a Critical Study," ILI Law Review, 19 (2016) $<$ https://ili.ac.in/pdf/paper10.pdf>

Silvana, Hana, dan Cecep, "Pendidikan Literasi Digital Di Kalangan Usia Muda Di Kota Bandung," Pedagogia : Jurnal Ilmu Pendidikan, 16.2 (2018)

Suhayati, Monika, "Larangan Penghinaan dan/atau Pencemaran Nama Baik Dalam Pasal 27 Ayat (3) UU ITE," Info Singkat, 13.5 (2021)

Supiyati, "Penerapan Pasal 27 Ayat 3 Undang-Undang No 19 Tahun 2016 Tentang Informasi Dan Transaksi Elektronik Terhadap Tindak Pidana Pencemaran Nama Baik Melalui Internet Sebagai Cybercrime Di Hubungkan Dengan Kebebasan Berekspresi," Pamulang Law Review, $2.1(2020)$

Thamrun, Sean Clara, "Delik Pencemaran Nama Baik Dalam Undang-Undang Informasi Dan Transaksi Elektronik Ditinjau Dari Prespektif HAM," Jurnal Education and development, 8.2 (2020)

\section{Peraturan Perundang-undangan}

Undang Dasar Negara Republik Indonesia Tabun 1945

Kitab Undang-Undang Hukum Pidana

Undang-Undang Nomor 19 Tabun 2016 tentang Perubaban Atas Undang-Undang Nomor 11 Tabun 2008 tentang Informasi dan Transaksi Elektronik.

\section{Sumber Lain}

CNN Indonesia, "Pedoman Interpretasi UU ITE di Tengah Desakan Revisi Pasal," CNN Indonesia, $2021<$ https://www.cnnindonesia.com/nasional/20210218120427-20-607829/pedomaninterpretasi-uu-ite-di-tengah-desakan-revisi-pasal $>$ 
, "Polri Tangani 4.656 Kasus Siber, Pencemaran Nama Baik Dominan," CNN Indonesia, 2020

Erdianto, Tsarina, "Mengenal Virtual Police: Definisi, Dasar Hukum, hingga Polemiknya," Kompas.com, 2021 < https://nasional.kompas.com/read/2021/03/17/14414171/mengenalvirtual-police-definisi-dasar-hukum-hingga-polemiknya?page $=$ all $>$

Ervilia Agustine Wiharsianti, "Hak Asasi Manusia: Kebebasan Berpendapat,” Kompasiana, 2014 <https://www.kompasiana.com/erviliaagustine/hak-asasimanusia-kebebasanberpendapat_54f98577a3331140548b4836>

Griffen, Scott, BRIEFING : CRIMINAL DEFAMATION (Vienna / Austria, 2015)

LBH Makassar, LBH Apik Makassar, YLBHM, Koalis Peduli Demokrasi (Kopidemo) Makassar, "Yusniar Bebas dari Jerat Kriminalisasi, Bukti UU ITE Bermasalah," Lbhmakassar.org, 2017 $<$ https://lbhmakassar.org/press-release/yusniar-bebas-dari-jerat-kriminalisasi-bukti-uu-itebermasalah $/>$

Luxiana, Kadek Melda, "Berkaca dari Inggris, Hotman Paris Usul ke Mahfud UU ITE Jadi Perdata," detik.com, 2021 <https://news.detik.com/berita/d-5500922/berkaca-dari-inggrishotman-paris-usul-ke-mahfud-uu-ite-jadi-perdata $>$

Safenet, "Daftar Kasus Netizen yang Terjerat UU ITE," Safenet.or.id, 2020 $<$ https://id.safenet.or.id/daftarkasus/>

Startup Decisions, "Singapore's Defamation Law," startupdecisions.com.sg $<$ https://www.startupdecisions.com.sg/singapore/business-laws/defamation-law/>

Stephanie, Conney, “6 'Korban' yang Dijerat Pasal Karet UU ITE," Kompas.com, 2021 $<$ https://tekno.kompas.com/read/2021/02/16/15030007/6-korban-yang-dijerat-pasalkaret-uu-ite?page $=$ all $>$ 